\title{
Lithosphere mapping in the south- western margin of the São Francisco Craton
}

\author{
LYNTHENER B. TAKENAKA ${ }^{1,3 *}$, WILLIAM L. GRIFFIN ${ }^{2}$, \\ SuZANNE Y. O'REILlY ${ }^{2}$, Miguel A.S. BASEI ${ }^{3}$, CARLOS \\ E. GANADE ${ }^{1}$, DORRIT E. JACOB ${ }^{2}$ \\ ${ }^{1}$ Geodynamics Division, Geological Survey of Brazil, Brazil \\ *lynthener.oliveira@cprm.gov.br \\ ${ }^{2}$ CCFS and GEMOC, Dept. Earth and Environmental \\ Science, Macquarie University, NSW Australia, 2109 \\ ${ }^{3}$ Geosciences Intitute, University of São Paulo, São Paulo, \\ Brazil, 05508-900
}

Geophysical data from the southewesten edge of the São Francisco Craton indicate a cratonic Subcontinental Lithospheric Mantle (SCLM) of variable thickness, which may extend to the Southern Brasilia Belt. Many Cretaceous kimberlites and related rocks intruded the region (ca. 74-120 $\mathrm{Ma}$ ), sampling the lithospheric mantle mainly in areas of lower seismic velocity reflecting a shallow SCLM. Geothermobarometry of garnet xenocrysts from these pipes defines geotherms between $40-45 \mathrm{~mW} / \mathrm{m}^{2}$ and the base of the depleted lithosphere (BDL) is inferred at depths of about 90$160 \mathrm{Km}$. Dominant garnet populations are lherzolitic and Caharzburgitic, with minor wehrlitic; the proportion of sinuous REE patterns increases from northwest to southeast pipes. The effects of heating and melt-metasomatism are pronounced in some kimberlites including Limpeza-36 and Indaiá-10 and may extend to shallower depths in some pipes (e.g., below $80 \mathrm{~km}$ in Catalão-1B). Some high temperatures associated with metasomatic signatures likely reflect a kinked geotherm due to hot asthenospheric melt infiltration.

Although the area includes some recognized primary diamond sources as Canastra-1 kimberlite of $120 \mathrm{Ma}$ [1] and known diamond-bearing kimberlites as Três Ranchos-4, the available geochemical data so far, define an SCLM, at the time of xenolith entrainment, of variable thickness that can be considered generally thin relative to cratonic SCLM LAB depths $(\sim 180-220 \mathrm{~km})$. This is consistent with seismic tomography and magnetotellurics images, especially in the southeast. This latter SCLM has been affected by melt-related metasomatism, as shown in previous mantle xenoliths studies [1]. Such thin and relatively hot continental lithosphere suggests that any diamonds in these pipes are relics that have survived heating and uplift of the SCLM.

[1] Chaves et al, 2008b. Geociências, 27, 299-317. 